\title{
Simulation Study of Robust Geographically Weighted Empirical Best Linear Unbiased Predictor on Small Area Estimation*
}

\author{
Simulasi Metode Prediksi Tak Bias Linier Terbaik Empiris Terboboti \\ Geografis Kekar pada Pendugaan Area Kecil
}

\author{
Naima Rakhsyanda ${ }^{1}$, Kusman Sadik ${ }^{2 \ddagger}$, and Indahwati ${ }^{3}$ \\ ${ }^{1,2,3}$ Department of Statistics, IPB University, Indonesia \\ ‡corresponding author: kusmans@apps.ipb.ac.id
}

Copyright @ 2021 Naima Rakhsyanda, Kusman Sadik, and Indahwati. This is an open-access article distributed under the Creative Commons Attribution License, which permits unrestricted use, distribution, and reproduction in any medium, provided the original work is properly cited.

\begin{abstract}
Small area estimation can be used to predict the population parameter with small sample sizes. For some cases, the population units that are close spatially may be more related than units that are further apart. The use of spatial information like geographic coordinates are studied in this research. Outlier contaminations can affect small area estimations. This study was conducted using simulation methods on generated data with six scenarios. The scenarios are the combination of spatial effects (spatial stationary and spatial non-stationary) with outlier contamination (no outlier, symmetric outliers, and non-symmetric outliers). The purpose of this study was to compare the geographically weighted empirical best linear unbiased predictor (GWEBLUP) and robust GWEBLUP (RGWEBLUP) with direct estimator, EBLUP, and REBLUP using simulation data. The performance of the predictors is evaluated using relative root mean squared error (RRMSE). The simulation results showed that geographically weighted predictors have the smallest RRMSE values for scenarios with spatial non-stationary, therefore offer a better prediction. For scenarios with outliers, robust predictors with smaller RRMSE values offer more efficiency than non-robust predictors.
\end{abstract}

Keywords: geographically weighted, outlier, small area estimation, spatial nonstationary.

\footnotetext{
* Received: Aug 2020; Reviewed: Des 2020; Published: Mar 2021
} 


\section{Pendahuluan}

Pada proses pengambilan contoh, suatu area dikatakan kecil jika ukuran contoh pada area tersebut tidak cukup untuk menghasilkan pendugaan langsung dengan presisi yang memadai (Rao, 2003). Pendugaan area kecil (small area estimation, SAE) merupakan suatu metode untuk menghasilkan penduga dari parameter populasi pada area dengan ukuran contoh kecil. Ukuran contoh yang kecil dapat menyebabkan keragaman pendugaan yang besar, bahkan pendugaan mungkin tidak dapat dilakukan ketika suatu area tidak terpilih sebagai contoh (Sadik, 2009). Salah satu metode pengumpulan data yang dirancang untuk dapat menduga parameter populasi dengan mengambil sebagian anggota populasi sebagai contoh adalah survei. Survei menyajikan suatu cara yang efisien terhadap biaya untuk mendapatkan pendugaan parameter yang diteliti, terutama pada tingkat regional yang lebih tinggi (negara atau provinsi). Pada banyak situasi, ukuran contoh yang diambil pada tingkat regional yang lebih rendah (kabupaten atau kecamatan) tidak cukup besar untuk memberikan pendugaan langsung yang memadai (Baldermann et al., 2018). Prediksi tak bias linier terbaik empiris (Empirical Best Linear Unbiased Prediction, EBLUP) merupakan salah satu metode penyelesaian model linier campuran yang sering digunakan pada pendugaan area kecil.

Dalam pendugaan area kecil biasanya diasumsikan bahwa unit populasi pada area kecil yang berbeda tidak saling berkorelasi. Namun terdapat beberapa kasus ketika unit-unit yang dekat secara spasial lebih berkaitan daripada unit-unit yang jaraknya lebih jauh, meskipun unit-unit tersebut mungkin berada pada area kecil yang berbeda (Chandra et al., 2012). Suatu metode yang belakangan ini dilakukan adalah dengan memasukkan informasi spasial seperti titik koordinat dan jarak antara area kecil yang berada pada proses pendugaan. Hal ini didasarkan pada asumsi bahwa area yang berdekatan lebih memiliki kemiripan dibandingkan dengan area yang berjauhan (Baldermann et al., 2018). Beberapa penelitian (Baldermann et al., 2018; Chandra et al., 2012; Pratesi \& Salvati, 2008) menunjukkan bahwa pendugaan area kecil dengan memanfaatkan informasi spasial dapat memberikan keuntungan jika dipandang dari segi efisiensi.

Heterogenitas spasial dapat dikatakan sebagai ketidakstabilan struktural dalam bentuk keragaman galat yang tidak konstan (heteroskedastisitas). Salah satu pendekatan untuk memasukkan heterogenitas spasial mengasumsikan bahwa koefisien-koefisien regresi berbeda atau berubah-ubah secara spasial sepanjang area kecil yang diteliti. Kondisi seperti ini disebut sebagai spasial non-stasioner (Brunsdon et al., 1996; Fotheringham et al., 2003). Sebaliknya, kondisi spasial stasioner adalah keadaan ketika koefisien-koefisien regresi tidak berbeda atau tidak berubah secara spasial pada area-area yang diteliti. Suatu prediksi tak bias linier terbaik empiris terboboti geografis (Geographically Weighted Empirical Best Linear Unbiased Predictor, GWEBLUP) diusulkan oleh Chandra et al., (2012) untuk pendugaan area kecil. GWEBLUP didasarkan pada model campuran pada kondisi spasial non-stasioner baik untuk pengaruh tetap linier (linear fixed effects) maupun pengaruh acak area (random area effects). Bobot yang digunakan pada GWEBLUP adalah fungsi dari jarak antara titik-titik data contoh.

Pencilan merupakan observasi dengan nilai yang sangat berbeda jika dibandingkan dengan semua contoh secara keseluruhan (R. L. Chambers, 1986). 
Menurut Draper \& Smith (1998), pencilan merupakan suatu pengamatan yang nilainya menyimpang agak jauh dari pengamatan lainnya dan mungkin berada pada jarak tiga atau empat kali simpangan baku atau lebih jauh dari nilai tengahnya. Pencilan dapat menyebabkan sebaran data menjadi tidak simetris sehingga asumsi kenormalan tidak terpenuhi. Untuk mengatasi keberadaan pencilan digunakan suatu metode regresi kekar untuk memperoleh dugaan yang stabil meskipun terdapat kontaminasi pencilan pada data. Terdapat dua tipe kontaminasi pencilan yang digunakan pada penelitian ini, yaitu pencilan simetris dan pencilan non-simetris. Kontaminasi pencilan simetris disebabkan oleh pengambilan contoh dari campuran distribusi dengan nilai tengah sama dan standar deviasi yang berbeda. Kontaminasi non-simetris disebabkan oleh pengambilan contoh dari campuran distribusi dengan nilai-nilai tengah yang berbeda (Liu \& Zumbo, 2007). Sinha \& Rao (2009) mengusulkan prediksi tak bias linier terbaik empiris kekar (Robust Empirical Best Linear Unbiased Predictor, REBLUP) untuk mengatasi keberadaan pencilan pada pendugaan area kecil. Schmid \& Münnich (2014) serta Schmid et al. (2016) mengusulkan penduga robust projective dan robust predictive dalam kondisi pengaruh acak yang berkorelasi secara spasial. Baldermann et al. (2018) mengusulkan penduga area kecil kekar pada kondisi spasial nonstasioner dalam model campuran linier lokal yang disebut prediksi tak bias linier terbaik empiris terboboti geografis kekar (Robust Geographical Weighted Empirical Best Linear Unbiased Predictor, RGWEBLUP). Metode ini diharapkan dapat menghasilkan pendugaan dengan presisi yang baik pada data yang berdistribusi tidak normal dan memiliki pengaruh spasial.

Pada penelitian ini akan dilakukan simulasi dengan menggunakan data yang dibangkitkan dengan menambahkan informasi pengaruh spasial dan kontaminasi pencilan. Pendugaan nilai parameter populasi dilakukan dengan metode pendugaan langsung, EBLUP, REBLUP, GWEBLUP, dan RGWEBLUP. Evaluasi model akan dilakukan dengan menggunakan Relative Bias (RB) dan Relative Root Mean Squared Error (RRMSE). Tujuan dari penelitian ini adalah mengkaji simulasi metode pendugaan GWEBLUP dan RGWEBLUP pada pendugaan area kecil serta membandingkan hasilnya dengan penduga langsung, EBLUP, dan REBLUP.

\section{Metodologi}

\subsection{Data}

Simulasi pada penelitian ini dilakukan dengan merujuk kepada metode simulasi pada (Baldermann et al., 2018). Data populasi pada simulasi dibangkitkan dengan banyaknya area kecil $m=40$ dan total populasi $N=4000$. Peubah $x_{i j}$, pengaruh acak area $v_{i}$ dan galat penarikan contoh $e_{i j}$ dibangkitkan sesuai kondisi skenario yang akan diamati. Terdapat enam rancangan skenario yang merupakan kombinasi dari pengaruh spasial dan kontaminasi pencilan (Tabel 1).

\subsection{Metode Penelitian}

Tahapan simulasi yang dilakukan adalah sebagai berikut.

1. Membangkitkan data populasi sebesar $N=4000$ dengan $m=40$ area kecil. Untuk semua area, ukuran populasi dan contoh ditetapkan pada $N_{i}=100$ dan $n_{i}=5 ; i=$ $1, \ldots, m$. 
Tabel 1: Skenario simulasi

\begin{tabular}{|c|c|c|}
\hline Skenario & Pengaruh Spasial & Kontaminasi Pencilan \\
\hline 1 & Spasial non-stasioner & Tidak terdapat pencilan \\
\hline 2 & Spasial non-stasioner & $\begin{array}{l}\text { Terdapat pencilan simetris pada pengaruh } \\
\text { acak area dan galat pengambilan contoh }\end{array}$ \\
\hline 3 & Spasial stasioner & Tidak terdapat pencilan \\
\hline 4 & Spasial stasioner & $\begin{array}{l}\text { Terdapat pencilan simetris pada pengaruh } \\
\text { acak area dan galat pengambilan contoh }\end{array}$ \\
\hline 5 & Spasial non-stasioner & $\begin{array}{l}\text { Terdapat pencilan non-simetris pada pengaruh } \\
\text { acak area dan galat pengambilan contoh }\end{array}$ \\
\hline 6 & Spasial stasioner & $\begin{array}{l}\text { Terdapat pencilan non-simetris pada pengaruh } \\
\text { acak area dan galat pengambilan contoh }\end{array}$ \\
\hline
\end{tabular}

2. Membangkitkan peubah penyerta yang mengikuti sebaran lognormal dengan nilai tengah 1 dan standar deviasi 0.5 (Chambers et al., 2014).

$x_{i j} \sim \operatorname{lognormal}(\mu=1, \sigma=0.5)$

3. Membangkitkan peubah respon $y_{i j}$ berdasarkan persamaan berikut.

$$
y_{i j}=\beta_{0(i j)}+\beta_{1(i j)} x_{i j}+v_{i}+e_{i j}
$$

dengan

$$
\begin{gathered}
\beta_{0(i j)}=100+a_{0}\left(\text { longitude }_{i j}+\text { latitude }_{i j}\right) \\
\beta_{1(i j)}=5+a_{1}\left(\text { longitude }_{i j}+\text { latitude }_{i j}\right)
\end{gathered}
$$

3.1. Membangkitkan koordinat-koordinat populasi (longitude dan latitude) sebagai suatu kotak-kotak persegi (grid) dari titik-titik pada wilayah $[0, \sqrt{N} / 2] \times$ $[0, \sqrt{N} / 2]$.

3.2. Menetapkan parameter $a_{0}$ dan $a_{1}$ yang mendefinisikan variasi spasial dari koefisien model pada model populasi. Berdasarkan (Chandra et al., 2012b), untuk skenario pada kondisi spasial stasioner ditetapkan nilai $a_{0}=a_{1}=0$ dan untuk skenario pada kondisi heterogenitas spasial (spasial non-stasioner) ditetapkan nilai $a_{0}=0.1$ dan $a_{1}=0.2$.

4. Mengambil contoh dari populasi dengan penarikan contoh acak sederhana tanpa pengembalian dari setiap area.

5. Membangkitkan pengaruh acak (random effects) $v_{i}$ dan galat penarikan contoh (individual error) $e_{i j}$ secara independen dalam mekanisme kontaminasi pencilan yang berbeda:

(i) $(0,0)$ - tidak ada pencilan, $v_{i} \sim N(0,4)$ dan $e_{i j} \sim N(0,8)$;

(ii) $(v, e)_{s}$ - pencilan simetris pada pengaruh acak area dan galat penarikan contoh, $v_{i} \sim N(0,4)$ untuk area 1-36 dan $v_{i} \sim N(0,25)$ untuk area 37-40; $e_{i j} \sim$ $\delta N(0,8)+(1-\delta) N(0,160) ; \delta$ berdistribusi Bernoulli dengan $P(\delta=1)=0.95$;

(iii) $(v, e)_{n s}$ - pencilan non-simetris pada pengaruh acak area dan galat penarikan contoh, $v_{i} \sim N(0,4)$ untuk area 1-36 dan $v_{i} \sim N(12,25)$ untuk area 37-40; $e_{i j} \sim$ $\delta N(0,8)+(1-\delta) N(25,160) ; \delta$ berdistribusi Bernoulli dengan $P(\delta=1)=$ 0.95 . 
6. Menghitung nilai pendugaan langsung untuk rata-rata peubah respon $y_{i j}$.

7. Melakukan pendugaan tidak langsung untuk menghitung rata-rata peubah $y_{i j}$ pada setiap kombinasi kondisi spasial dan pencilan dengan menggunakan penduga EBLUP, REBLUP, GWEBLUP, dan RGWEBLUP.

8. Mengulangi langkah 6 dan 7 sebanyak $T=100$ kali secara independen.

9. Mengevaluasi penduga dengan Relative Bias (RB) yang spesifik terhadap area dan Relative Root Mean Squared Error (RRMSE) yang diberikan dengan

$$
\begin{gathered}
R B\left(\hat{\bar{y}}_{i}\right)=\frac{1}{T} \sum_{t=1}^{T} \frac{\hat{y}_{t i}-\bar{y}_{t i}}{\bar{y}_{t i}} \\
\operatorname{RRMSE}\left(\hat{\bar{y}}_{i}\right)=\sqrt{\frac{1}{T} \sum_{t=1}^{T}\left(\frac{\hat{y}_{t i}-\bar{y}_{t i}}{\bar{y}_{t i}}\right)^{2}}
\end{gathered}
$$

\section{Hasil dan Pembahasan}

\subsection{Data Simulasi}

Pembangkitan data populasi menghasilkan 4000 unit populasi dalam 40 area dengan koordinat-koordinat populasi berupa kotak-kotak persegi (Gambar 1). Pada setiap area terdapat sekitar 100 unit. Nilai peubah respon tiap skenario akan bervariasi sesuai dengan kondisi pengaruh spasial dan kontaminasi pencilan pada setiap skenario. Pada setiap area diambil contoh berukuran 5 yang akan digunakan untuk menghitung nilai dugaan rata-rata parameter populasi.

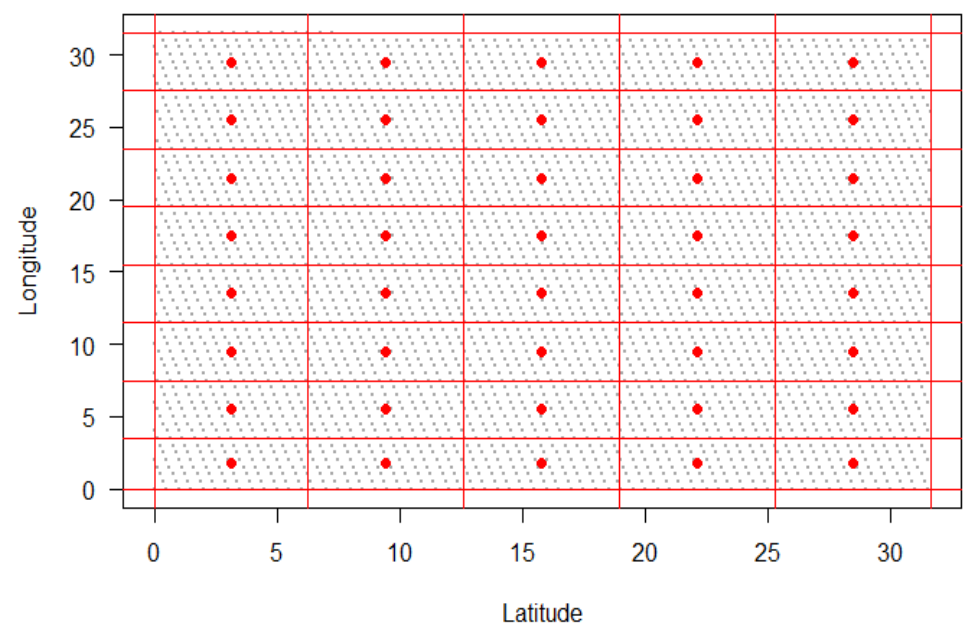

Gambar 1: Populasi hasil pembangkitan data simulasi

\subsection{Pendugaan Parameter}

Nilai dugaan rata-rata parameter dihitung berdasarkan pendugaan langsung, EBLUP, REBLUP, GWEBLUP, dan RGWEBLUP untuk masing-masing area pada Skenario 1 sampai Skenario 6. Tabel 2 menyajikan contoh perbandingan nilai parameter yang 
sesungguhnya dengan hasil pendugaan melalui pendugaan langsung dan tidak langsung pada Skenario 1.

Tabel 2: Perbandingan rataan hasil dugaan langsung dan tidak langsung pada

Skenario 1

\begin{tabular}{crrrrrr}
\hline Area & Parameter & Langsung & EBLUP & REBLUP & GWEBLUP & RGWEBLUP \\
\hline 1 & 122.514 & 121.593 & 124.229 & 125.191 & 122.664 & 124.419 \\
2 & 121.703 & 122.037 & 122.448 & 123.655 & 122.526 & 122.426 \\
3 & 126.668 & 126.333 & 127.478 & 127.847 & 126.274 & 126.155 \\
4 & 124.956 & 125.235 & 125.606 & 125.772 & 125.986 & 126.117 \\
5 & 128.859 & 129.184 & 129.239 & 129.272 & 129.092 & 129.188 \\
6 & 135.658 & 136.354 & 135.899 & 135.869 & 135.417 & 135.484 \\
$\ldots$ & & & $\ldots$ & & & \\
40 & 162.353 & 163.362 & 161.423 & 160.907 & 161.179 & 161.017 \\
\hline
\end{tabular}

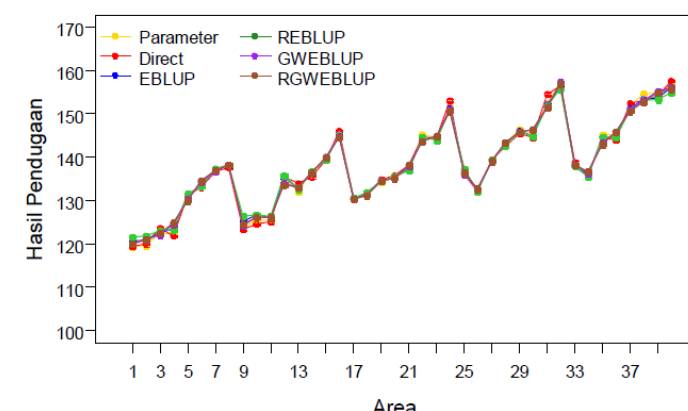

(a)

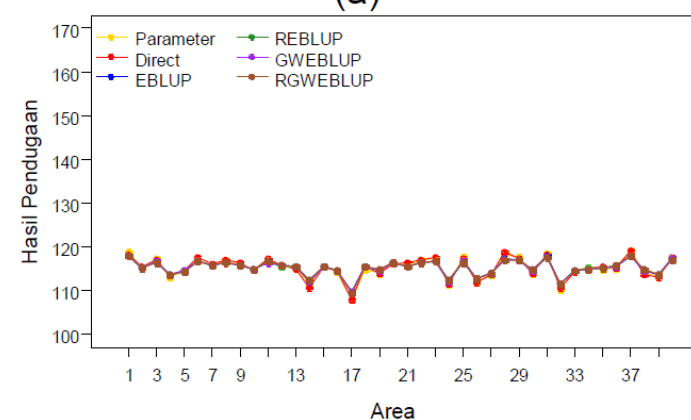

(c)

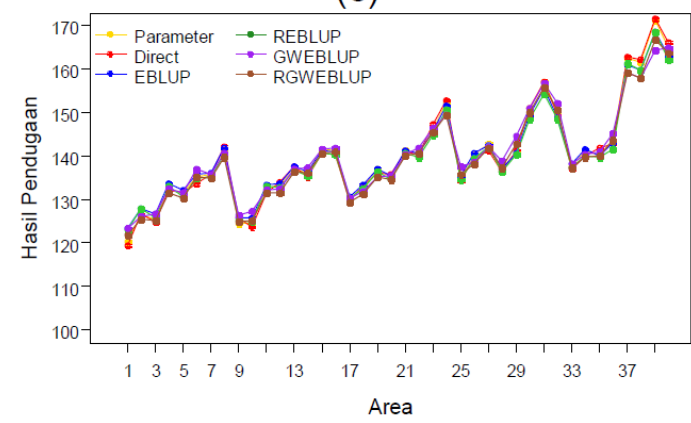

(e)

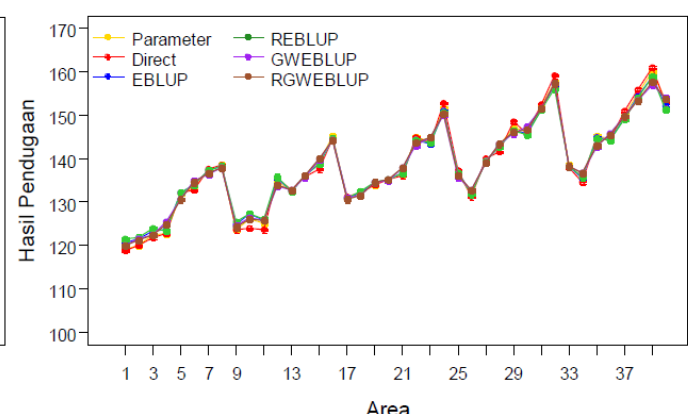

(b)

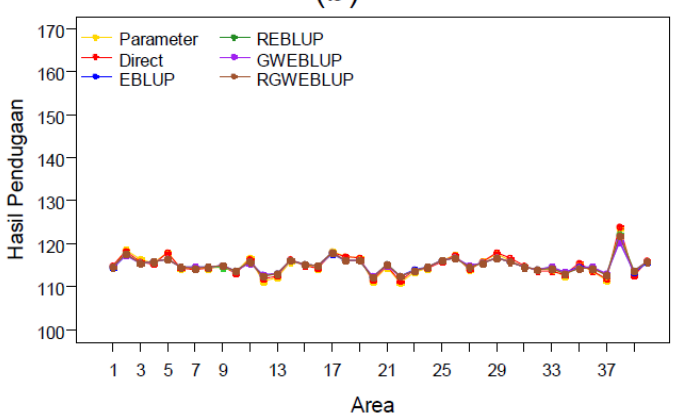

(d)

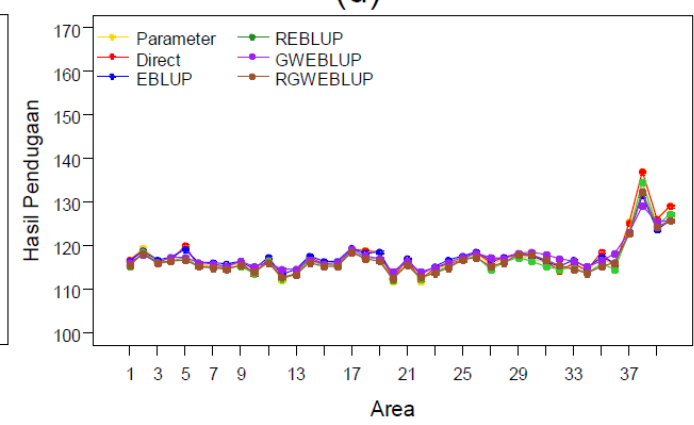

(f)

Gambar 2: Perbandingan hasil pendugaan langsung dan tidak langsung pada masing-masing area untuk (a) Skenario 1, (b) Skenario 2, (c) Skenario 3, (d) Skenario 4, (e) Skenario 5, dan (f) Skenario 6 
Tabel 2 memperlihatkan bahwa hasil pendugaan parameter dengan pendugaan langsung dan tidak langsung memberikan hasil yang berbeda-beda. Plot perbandingan hasil pendugaan untuk semua area per skenario disajikan pada Gambar 2. Secara eksploratif, plot hasil pendugaan baik langsung maupun tidak langsung secara umum memiliki pola yang berbeda tergantung pengaruh spasial pada setiap skenario.

Pengaruh spasial stasioner dan stasioner pada populasi dapat terlihat pada Gambar 2. Hasil pendugaan untuk data populasi dengan pengaruh spasial nonstasioner (Skenario 1, Skenario 2, dan Skenario 5) memiliki pola yang berbeda dengan hasil pendugaan untuk populasi dengan kondisi spasial stasioner (Skenario 3, Skenario 4, dan Skenario 6). Keberadaan pencilan dapat terlihat pada plot hasil pendugaan pada bagian paling kanan (area 37 sampai 40 ).

\subsection{Pemilihan Model Terbaik}

Kebaikan model dievaluasi dengan menggunakan bias relatif (Relative Bias/RB) dan galat relatif (Relative Root Mean Square Error/RRMSE) di setiap area. Tabel 3 menunjukkan ringkasan hasil simulasi yang dilakukan pada enam skenario. Setiap penduga dievaluasi menggunakan nilai median dari RB dan RRMSE. Penentuan penduga yang paling efisien dari setiap skenario dilakukan dengan melihat nilai median RRMSE. Nilai RRMSE yang lebih kecil mengindikasikan bahwa penduga tersebut lebih efisien. Pada semua skenario, pendugaan langsung menghasilkan nilai median RB dan RRMSE yang lebih besar jika dibandingkan dengan penduga area kecil (EBLUP, REBLUP, GWEBLUP, dan RGWEBLUP).

Tabel 3: Ringkasan hasil simulasi pada enam skenario data

\begin{tabular}{ccccccc}
\hline Penduga & SK 1 & SK 2 & SK 3 & SK 4 & SK 5 & SK 6 \\
\hline \multicolumn{7}{c}{ Nilai median dari RB $(\%)$} \\
Langsung & -0.019 & -0.113 & 0.021 & -0.025 & -0.125 & 0.031 \\
EBLUP & 0.000 & -0.073 & 0.004 & -0.035 & 0.121 & 0.356 \\
REBLUP & 0.030 & -0.026 & -0.029 & -0.009 & -0.471 & -0.586 \\
GWEBLUP & 0.118 & -0.054 & -0.006 & -0.052 & 0.030 & 0.110 \\
RGWEBLUP & 0.123 & 0.012 & -0.003 & -0.096 & -0.609 & -0.631 \\
\multicolumn{7}{c}{ Nilai median dari RRMSE $(\%)$} \\
Langsung & 5.840 & 5.792 & 3.277 & 3.312 & 5.910 & 3.814 \\
EBLUP & 1.389 & 1.654 & 0.881 & 1.092 & 2.366 & 1.867 \\
REBLUP & 1.386 & 1.472 & 0.888 & 0.977 & 1.819 & 1.171 \\
GWEBLUP & 0.824 & 0.991 & 0.900 & 1.123 & 1.449 & 1.720 \\
RGWEBLUP & 0.949 & 0.963 & 0.921 & 1.056 & 1.093 & 1.294 \\
\hline
\end{tabular}

Skenario 1 dan Skenario 3 merupakan kondisi di mana data tidak memiliki pencilan. Pada Skenario 1, penduga yang terboboti geografis (GWEBLUP dan RGWEBLUP) memiliki nilai median RRMSE yang lebih kecil dibandingkan penduga global (EBLUP dan REBLUP). Kebalikannya, pada Skenario 3 nilai median RRMSE bagi EBLUP dan REBLUP lebih kecil daripada GWEBLUP dan RGWEBLUP. Berdasarkan hal tersebut, untuk data tanpa pencilan, jika pada data terdapat kondisi spasial non-stasioner (Skenario 1), maka penduga terboboti geografis akan lebih efisien dibandingkan 
dengan penduga global yang tidak memasukkan unsur geografis. Pada Skenario 1, nilai median RB dan RRMSE pada penduga GWEBLUP lebih kecil daripada RGWEBLUP, sehingga penduga GWEBLUP akan menghasilkan dugaan yang lebih efisien dibandingkan RGWEBLUP. Jika terdapat kondisi spasial stasioner (Skenario 3), maka penduga global akan lebih efisien dibandingkan dengan penduga yang terboboti geografis. Pada Skenario 3, nilai median RRMSE penduga EBLUP lebih kecil daripada REBLUP, sehingga penduga EBLUP dapat memberikan hasil yang lebih efisien daripada REBLUP.

Pada hasil pendugaan data yang memiliki pencilan simetris (Skenario 2 dan Skenario 4), penduga kekar (REBLUP dan RGWEBLUP) memiliki nilai median RRMSE yang lebih kecil daripada penduga non-kekar yang sepadan dengannya (EBLUP dan GWEBLUP). Berdasarkan hal tersebut, pada kondisi terdapat pencilan simetris, penduga REBLUP lebih efisien daripada EBLUP dan penduga RGWEBLUP lebih efisien daripada GWEBLUP. Pada kondisi spasial non-stasioner (Skenario 2), penduga yang terboboti geografis lebih efisien dibandingkan penduga global. Nilai median RRMSE RGWEBLUP lebih kecil daripada GWEBLUP, sehingga pada kondisi spasial non-stasioner dengan pencilan simetris, RGWEBLUP akan memberikan hasil dugaan yang lebih efisien dibandingkan dengan penduga lainnya. Pada kondisi spasial stasioner (Skenario 4), penduga global memiliki nilai median RRMSE yang lebih kecil daripada penduga terboboti geografis.

Pada kondisi terdapat kontaminasi pencilan non-simetris (Skenario 5 dan Skenario 6), penduga kekar memiliki nilai median RRMSE yang lebih kecil dibandingkan penduga non-kekar. Namun, pada skenario ini penduga REBLUP dan RGWEBLUP memiliki nilai median $\mathrm{RB}$ yang lebih besar, baik pada kondisi spasial stasioner maupun spasial non-stasioner. Untuk data yang memiliki kondisi spasial non-stasioner (Skenario 5), penduga terboboti geografis lebih efisien dibandingkan penduga global. Penduga RGWEBLUP lebih efisien daripada GWEBLUP. Pada data dengan kondisi spasial stasioner (Skenario 6), penduga REBLUP memiliki nilai median RRMSE yang paling kecil dibandingkan penduga lainnya.

Plot perbandingan hasil RRMSE pada masing-masing area untuk setiap skenario tersaji pada Gambar 3. Terlihat bahwa penduga langsung (direct) memiliki nilai RRMSE yang jauh lebih besar daripada penduga-penduga lainnya, terutama pada skenario dengan pengaruh spasial non-stasioner (Skenario 1, Skenario 2, dan Skenario 5). Secara umum, pada kasus spasial non-stasioner model GWEBLUP dan RGWEBLUP menghasilkan RRMSE yang lebih kecil dibandingkan EBLUP dan REBLUP.

Ringkasan penduga dengan nilai RRMSE terkecil berdasarkan skenario pada simulasi tersaji pada Tabel 4. Pemilihan metode pendugaan terbaik untuk setiap skenario simulasi didasarkan pada nilai RRMSE di mana penduga yang memiliki nilai RRMSE terkecil diharapkan dapat memberikan hasil pendugaan yang lebih efisien dibandingkan penduga-penduga lainnya. 


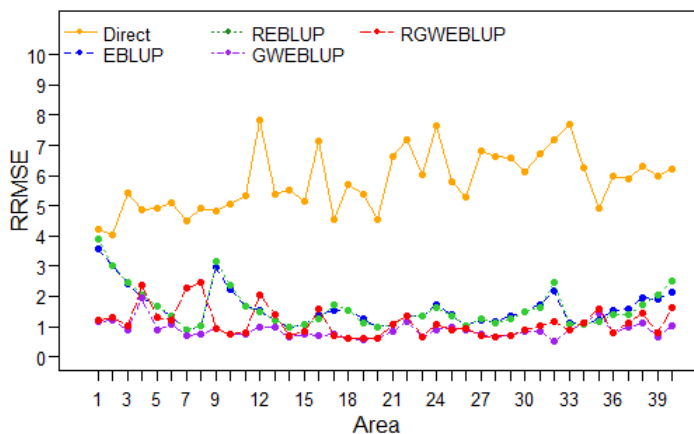

(a)

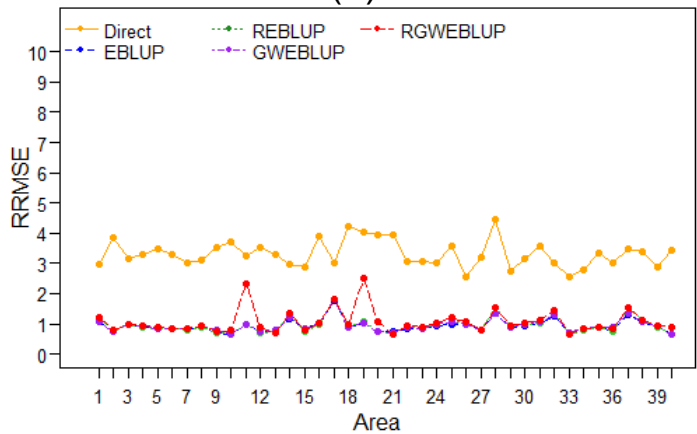

(c)

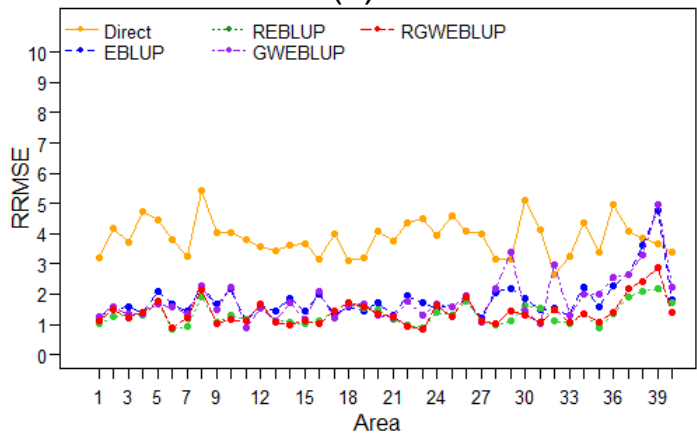

(e)

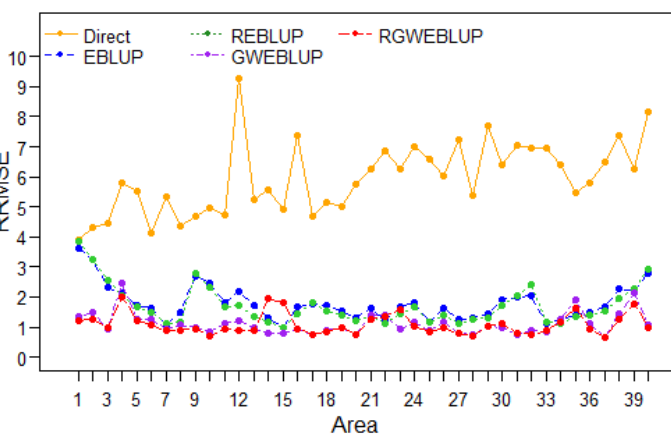

(b)

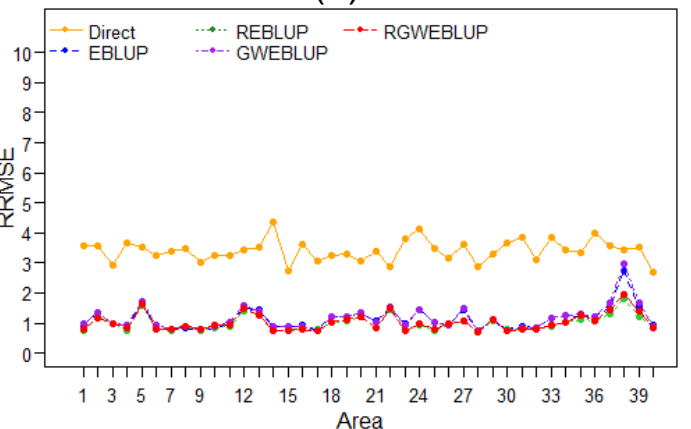

(d)

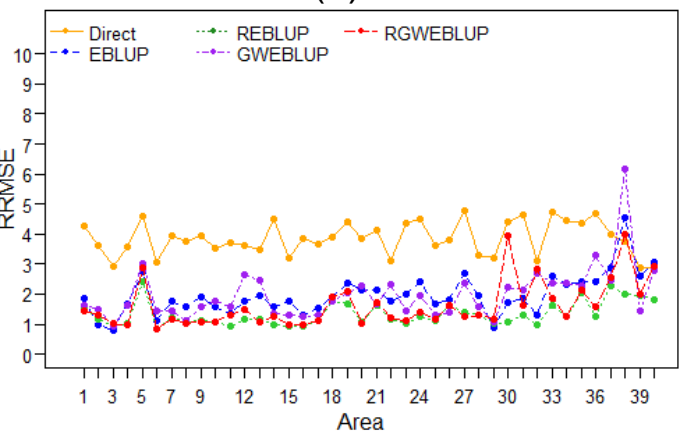

(f)

Gambar 3: Perbandingan hasil RRMSE pada masing-masing area untuk (a) Skenario

1, (b) Skenario 2, (c) Skenario 3, (d) Skenario 4, (e) Skenario 5, dan (f) Skenario 6

Tabel 4: Penduga dengan nilai RRMSE terkecil berdasarkan hasil simulasi

\begin{tabular}{ccc}
\hline Kontaminasi pencilan & Spasial stasioner & Spasial non-stasioner \\
\hline Tidak ada pencilan & EBLUP & GWEBLUP \\
Ada pencilan simetris & REBLUP & RGWEBLUP \\
Ada pencilan non-simetris & REBLUP & RGWEBLUP \\
\hline
\end{tabular}

\section{Simpulan}

Hasil simulasi menunjukkan bahwa pemilihan metode pendugaan yang sesuai dengan karakteristik data dapat memberikan hasil dugaan dengan nilai RRMSE yang lebih kecil. Penggunaan penduga yang terboboti geografis (GWEBLUP dan RGWEBLUP) pada data yang memiliki pengaruh spasial non-stasioner memberikan nilai RRMSE 
yang lebih kecil dari penduga langsung dan penduga global (EBLUP dan REBLUP). Pada data dengan pengaruh spasial stasioner, nilai RRMSE dari penduga global lebih kecil daripada penduga terboboti geografis. Pada data yang terkontaminasi pencilan, penduga kekar menghasilkan nilai RRMSE yang lebih kecil dibandingkan penduga non-kekar.

\section{Daftar Pustaka}

Baldermann, C., Salvati, N., \& Schmid, T. (2018). Robust Small Area Estimation under Spatial Non-stationarity: Robust SAE under Spatial Non-Stationarity. International Statistical Review, 86(1): 136-159. https://doi.org/10.1111/insr.12245

Brunsdon, C., Fotheringham, A. S., \& Charlton, M. E. (1996). Geographically weighted regression: a method for exploring spatial nonstationarity. Geographical Analysis, 28(4): 281-298.

Chambers, R., Chandra, H., Salvati, N., \& Tzavidis, N. (2014). Outlier robust small area estimation. Journal of the Royal Statistical Society: Series B (Statistical Methodology), 76(1): 47-69. https://doi.org/10.1111/rssb.12019

Chambers, R. L. (1986). Outlier robust finite population estimation. Journal of the American Statistical Association, 81(396): 1063-1069.

Chandra, H., Salvati, N., Chambers, R., \& Tzavidis, N. (2012a). Small area estimation under spatial nonstationarity. Computational Statistics \& Data Analysis, 56(10): 2875-2888.

Chandra, H., Salvati, N., Chambers, R., \& Tzavidis, N. (2012b). Small area estimation under spatial nonstationarity. Computational Statistics \& Data Analysis, 56(10): 2875-2888. https://doi.org/10.1016/j.csda.2012.02.006

Draper, N. R., \& Smith, H. (1998). Applied regression analysis (Vol. 326). John Wiley \& Sons.

Fotheringham, A. S., Brunsdon, C., \& Charlton, M. (2003). Geographically weighted regression: the analysis of spatially varying relationships. John Wiley \& Sons.

Liu, Y., \& Zumbo, B. D. (2007). The impact of outliers on Cronbach's coefficient alpha estimate of reliability: Visual analogue scales. Educational and Psychological Measurement, 67(4): 620-634.

Pratesi, M., \& Salvati, N. (2008). Small area estimation: the EBLUP estimator based on spatially correlated random area effects. Statistical Methods and Applications, 17(1): 113-141.

Rao, J. (2003). Some new developments in small area estimation. Journal of The Iranian Statistical Society (JIRSS), 2(2): 145-169.

Sadik, K. (2009). Metode Prediksi Tak-Bias Linear Terbaik Dan BayesBerhirarki Untuk Pendugaan Area Kecil Berdasarkan Model State Space.

Schmid, T., \& Münnich, R. T. (2014). Spatial robust small area estimation. Statistical Papers, 55(3): 653-670. 
Schmid, T., Tzavidis, N., Münnich, R., \& Chambers, R. (2016). Outlier robust smallarea estimation under spatial correlation. Scandinavian Journal of Statistics, 43(3): 806-826.

Sinha, S. K., \& Rao, J. (2009). Robust small area estimation. Canadian Journal of Statistics, 37(3): 381-399. 